Received: 27-07-2020 | Revision: 27-09-2020 | Accepted: 21-11-2020

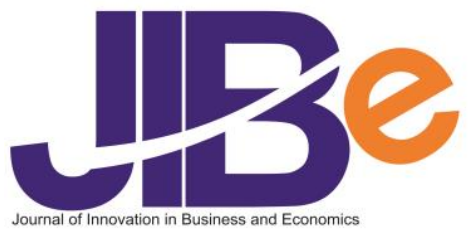

\title{
Challenges and strategies in developing human resources for the halal industry: Evidence from Indonesia
}

Sri Budi Cantika Yuli ${ }^{1}$, Edyta Wojtyla ${ }^{2}$

Faculty of Economics and Business, Universitas Muhammadiyah Malang, Indonesia ${ }^{l}$

WSB University in Poznan, Poland ${ }^{2}$

\begin{abstract}
The government has prioritized the development of the halal industry sector in Indonesia through the launch of the Indonesian Sharia Economics Master Plan (MEKSI) in 2019. Currently, Indonesia is in the 5th position in the world halal industry ecosystem. This is the main focus to strengthen Indonesia as a world halal producer in 2024. This study aims to examine the challenges of developing halal industry in Indonesia and try to provide a strategy for developing human resources (HR). This study applies a qualitative research approach using three stages of data analysis, namely data reduction, data presentation, and data verification. Data analysis techniques are supported by the NVivo 12 plus program. Based on the results of the literature study, several challenges were found related to the halal industry in Indonesia, i.e. Regulation, Human Resources (HR), Government, Infrastructure and Organization. This study compiles a human resource development strategy to face HR challenges, as follows 1) Human Resource Transformation through people transformation, cultural transformation, organizational transformation and 2) Human Resource Digitalization.
\end{abstract}

Keywords: Challenges; halal industry; regulation; human resources; government

\section{Introduction}

In recent decades, the halal industry is attracting the world's attention, both from the government and business sides. Halal industry enthusiasts are dominated by Muslim-majority countries such as Indonesia and Malaysia and attractive to non-Muslim countries such as Australia, Thailand, Singapore, United Kingdom, Italy, and others. The increasing interest of the world community to consume halal products is not solely due to the belief but also because halal products can guarantee good product quality in terms of ethics, health, safety, and environmental friendliness (Nadira, 2020). The concept is in line with Q.S. Al-Baqarah (2) Verse 58

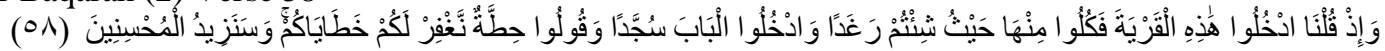

58. And 'remember' when We said, "Enter this city ( Bayt al-Maqdis) and eat freely from wherever you please; enter the gate with humility, saying, 'Absolve us.' We will forgive your sins and multiply the reward for the good-doers."

Based on data from The State of The Global Islamic Economy Report 2020/2021, the growth rate of Muslim spending in 2019 in various halal sectors, such as food and beverages, halal pharmaceuticals and cosmetics, halal clothing, halal tourism, halal media, and entertainment, and Islamic finance reached 3.2 percent (year on year) with a value of around the 2.2 trillion USD. This numeral is predicted to continue to grow to the 3 trillion USD in 2023. The main factor driving the increase in Muslim spending is the Muslim population globally, which has also increased to reach 1.84 billion people in 2017 and is expected to continue to rise to 27.5 percent of the total world population by 2030 (Dinar Standard, 2020).

The halal industry in Indonesia has become the key sector developed by the government through the 2019-2024 Indonesian Sharia Economic Master Plan (MEKSI) by President Joko Widodo on May 14, 2019. MEKSI's four main strategies comprise strengthening the halal value chain, firming the Islamic financial sector, establishing the Micro, Small, and Medium Enterprises (UMKM) sector, and supporting the digital economy. The formulation of the Master Plan has the main objective of making Indonesia a producer of the global halal industry by 2024 . The large Muslim population globally and the total Muslim population that Indonesia has, which is 222 million, is a great potential for Indonesia to become the epicenter of the world's halal producers. In 2020, in the midst of the Covid-19 virus pandemic, Indonesia succeeded in

\footnotetext{
${ }^{1}$ E-mail: cantika@umm.ac.id
} 
increasing its position to rank fourth in the Global Islamic Economic Indicator after previously occupying the 10th position in 2018 and the 5th position in 2019. The ranking increase is an important encouragement to continue and strengthen Indonesia as a world halal producer.

The government has made several efforts to develop Indonesia's potential as a world halal producer, but Indonesia's halal industry is still underdeveloped. Indonesia is still lagging behind other countries because of the many challenges faced by the halal industry in Indonesia. Several studies have been conducted related to the halal industry and its challenges in various fields, some of which are: research on the perception of halal by consumers (D. S. Sayogo, 2018; Warsito et al., 2020), research on the halal traceability system (Delma et al., 2015; D. Sayogo et al., 2017), research on the development of the halal industry which focuses on halal food ( Masrom et al., 2019; Limsuwan, 2019), focusing on fashion or clothing (Hanzaee \& Chitsaz, 2011; Martiana et al., 2018; Faried \& Sembiring, 2019), focusing on halal tourism (A.J. \& Jonathan, 2011; Jaelani, 2017; Ali Hasan \& Azis Muslimin, 2019), halal cosmetics (Arbak et al., 2019), Media and entertainment cluster (Nisha \& Iqbal, 2017; Rasit et al., 2019), as well as research on Islamic finance (Haseeb, 2018; Mujahidin, 2019).

Meanwhile, research on the challenges of the halal industry was carried out by (Satriana \& Faridah, 2018; Widiastuti et al., 2020; Anwar Fathoni \& Hadi Syahputri, 2020; Warto \& Arif, 2020; and Mubarok \& Imam, 2020), which explained that one of the challenges of the halal industry in Indonesia is the problem of Human Resources (HR). However, none of the previous studies have analyzed the challenges and strategies for developing Human Resources in the halal industry. In fact, it is essential to map the challenges and efforts to develop human resources in the Indonesian halal industry. Therefore, this study aims to determine the challenges and strategies for developing human resources in Indonesia's halal industry.

\section{Literature Review}

The halal food sector has undergone major changes in 2019. This was triggered by the development of halal central technology. Various mobile-based applications can now connect consumers with the desired halal brand restaurant. Also, the halal tracking platform connects all supply chains (halal value chain) from producers to auditors and certification bodies. For global potential, the UAE and China have signed an agreement worth 1 billion USD for a halal food manufacturing and processing plant in Dubai, while Indonesia plans to launch a Halal Lifestyle District worth 18 million USD. The Muslim community's spending on halal food and beverages amounted to 1.4 trillion USD in 2018 and is expected to reach 2.0 trillion USD by 2024 .

Reaching 2020, the Muslim fashion sector has experienced encouraging developments. This can be seen from the number of Muslim fashion events around the world that have spawned new brands and increased investment in Muslim fashion online sites, as achieved by the simple online retail Muslim fashion business Modanisa, which was able to sell minority shares estimated at 15 million USD to Goldman Sachs and Wamda Capital for financing expansion. In the meantime, The Modist, an online retailer based in Dubai, has attracted investment and the New York Haute Hijab fashion brand has received funding to create the first brand to cater to the lifestyle of the digital Muslim community. Muslim spending on clothing and footwear is estimated to be worth 283 billion USD in 2018 and is expected to grow to 402 billion USD by 2024.

The Muslim tourism sector, a cluster that discusses meeting the religious needs of Muslim tourists, is increasingly providing many choices today, ranging from choices of beach resorts or tourist destinations to family-oriented hotels, from travel agents to applications to book and assess holiday destinations. During 2019, many online travel agents already have a new focus on providing Umrah services to Saudi Arabia and other tourism. This sector attracts the largest investment in the Muslim-friendly travel market (Moslem friendly tourism). The government plans of OIC countries to increase tourism revenue further encourage investment in this sector, both in Malaysia and Indonesia, as well as Turkey and Saudi Arabia. Muslim consumer tourism spending was valued at 189 billion USD in 2018 and is expected to grow to 274 billion USD by 2024 .

In other sectors, the media and entertainment cluster increases the offering portfolio in the fields of films, miniseries online content, as well as applications for the lifestyle needs of the Muslim community. Studios and streaming platforms such as Netflix have adapted and created new content to attract Muslim consumers as well as the development of Islamic cultural values for child consumers on various platforms. Muslim community spending to meet their needs in the media and entertainment sector reached 220 billion USD in 2018 and is projected to increase to 309 billion USD in 2024. However, even though the investment and development of Islamic Economics are growing rapidly during 2020, it is still a lot of work to be done to improve it. For this reason, the SGIE report provides guidance for all stakeholders, including private investors, entrepreneurs, regulators, and the government, on how best to encourage the development of the 
media and entertainment sector, maximize its use on a substantial side and help realize the potential of the Islamic economy to serve its needs. 1.8 billion Muslim communities and the ethical needs of billions of other people who have different religions, beliefs, and lifestyles.

The following sector is pharmaceutical and cosmetics. This sector shows readiness to develop with the investment of companies that have a long-term vision and mission goals and have obtained halal certification. This readiness can especially be seen in Malaysia, Indonesia, and South Korea. On the other hand, the OIC member government encourages the manufacture of vaccines and halal medicines. Muslim consumer spending on medicine reached 92 billion USD in 2018 and is predicted to grow to reach 134 billion USD by 2024 . Halal cosmetics is a different growth area. New brands are starting to emerge and develop along with e-commerce that can help expand offerings and attract investment. For example, the halal cosmetics brand SimplySiti plans to register on the Malaysian stock exchange. Another example is Boutiqaat, which is in Kuwait, as a fashion and cosmetics e-commerce startup, has also increased its valuation to 500 million USD after securing funding from investment companies based in the Gulf. Muslim consumer cosmetics spending in the world is estimated to reach 64 billion USD in 2018 and will reach 95 billion USD in 2024.

Likewise, the potential of the Islamic financial sector can keep pace with the growth rate of rapid market changes, adopting FinTech, cryptocurrency, and digital banking. Also, more corporations and governments have issued Sukuk (Islamic financial bonds), including green Sukuk. However, even though FinTech is starting to push Islamic finance to a different level, the recent growth has come from conventional banking products and services. The Islamic finance industry is estimated to be worth 2.5 trillion USD in 2018 and is predicted to reach 3.5 trillion USD by 2024.

As a consequence, many challenges have arisen along with the incessant efforts to develop the potential of the halal industry in Indonesia towards the center of the world's halal industry. Research related to the challenges of the halal industry has been carried out (Suyudi et al., 2019) and (Muhamad, 2020), the challenges of the halal food sector (M. A. A. Majid et al., 2015; Suhaiza et al., 2017; (Waharini \& Purwantini, 2018), Muslim fashion sector (Izzuddin et al., 2019; Faried \& Sembiring, 2019); challenges in the halal tourism sector (Battour \& Ismail, 2016; Fahham, 2017; Satriana \& Faridah, 2018; Erhan \& Mehmet, 2019; Destiana \& Astuti, 2019; Rasul, 2019), the halal Media and Recreation sector (Nisha \& Iqbal, 2017; Abduttawwab, 2019); Halal Pharmacy and Cosmetics Sector (M. B. Majid et al., 2015; Aisyah, 2016; Briliana \& Mursito, 2017; Sugibayashi et al., 2019; Barizah, 2020) and the challenges of the Islamic financial sector (Baidhowi, 2018; Firmansyah \& Anwar, 2019; Maharani, 2020; Harrieti et al., 2020); and this research is the first research focused on the strategy of developing human resources in the halal industry in Indonesia.

\section{Research Method}

This qualitative descriptive study applies library research using secondary data obtained from scientific articles and other relevant documents. The data obtained were then analyzed to produce descriptive descriptions associated with the object of this study. There are three data analysis stages in this study, namely data reduction, data presentation, and data verification. In the data reduction stage, all data were selected through simplification and elimination of unnecessary data, according to the research topic. Subsequently, the research topic presented the reduced data, namely the challenges and strategies for developing human resources in the halal industry in Indonesia. The final phase is data verification to draw conclusions which are the researchers' interpretation of the data. Verification is completed using the triangulation technique, which compares one data source with another data source. The stages of data analysis in this study used document analysis techniques through the NVivo 12 plus program

\section{Result and Discussion}

Initially, researcher conducted a systematic literature study based on related journals to identify what challenges Indonesia faces to become the world's halal producer center. In the first stage of the iteration process, the results are obtained as in Table 2 and The second iteration stage is grouping into clusters, so that the 5 challenges faced by the halal industry in Indonesia.

First, the Government. The halal industry in Indonesia encounters the challenge of the Government's role in realizing Indonesia as the world's halal center in 2024. Challenges for the role of the Government include; The role of the Government has not been optimal in socializing the halal industry to the public, certification of halal products, certification of halal companies and socialization of consumer protection, as well as the role of the Government in regulating the mandatory halal logistics. The results of 
this study are similar to researches completed by (Hanzaee \& Chitsaz, 2011; Suhaiza et al., 2017; Suyudi et al., 2019; Widiastuti et al., 2020; Harrieti et al., 2020; Maharani, 2020)

Second, Organization. The challenges in this aspect are the lack of halal-certified organizations or companies, promotion challenges, information sharing, halal raw materials, low competitiveness of local products, challenges in the production process (halal value chain management), challenges in halal control and challenges in logistics processes. The results of this analysis are in line with several previous studies (Norazmi \& Lim, 2015; Jaelani, 2017; Waharini \& Purwantini, 2018; D. S. Sayogo, 2018; Suyudi et al., 2019; Abduttawwab, 2019; Widiastuti et al., 2020; Mubarok \& Imam, 2020).

Third, infrastructure. This aspect is still a challenge due to the lack of cooperation, coordination and collaboration between similar halal industry sectors, lack of accurate information regarding Halal certification and databases of companies involved in the halal industry process. The results of this study are in accordance with research conducted by (Suhaiza et al., 2017; Jaelani, 2017; Fahham, 2017; Nisha \& Iqbal, 2017; Abduttawwab, 2019; Maharani, 2020; Widiastuti et al., 2020; Mubarok \& Imam, 2020)

Fourth, Human Resources (HR). The human resource challenge in the halal industry in Indonesia involves business actors and the public. Based on the results of data analysis, challenges from the business actor include; unaware attitude of business actors about halal products or industry, low awareness of the importance of halal product certification, business actors are more pursuing profits, lack of compliance with halal criteria related to how business actors prepare raw materials, products, production facilities, written procedures for critical activities and traceability, the paradigm of business actors that halal certification is only for large companies.

The challenges come from the community as consumers are; low public awareness of halal products, halal logos, and halal certification. People have different standards for halal products, low public understanding of the urgency of developing the halal industry. The results of this study are in line with research conducted by (M. A. A. Majid et al., 2015; Jaelani, 2017; D. Sayogo et al., 2017; Fahham, 2017; Baidhowi, 2018; Suyudi et al., 2019; Erhan \& Mehmet, 2019; Destiana \& Astuti, 2019; Abduttawwab, 2019; Firmansyah \& Anwar, 2019; Maharani, 2020; Widiastuti et al., 2020; Anwar Fathoni \& Hadi Syahputri, 2020; Warto \& Arif, 2020; Muhamad, 2020; Mubarok \& Imam, 2020)

Fifth, Regulation. The halal industry in Indonesia faces challenges in regulatory aspects to standardize the governance of the halal industry. The regulatory challenges based on the results of data analysis in this study consist of; Not all products are certified or standardized for halal products, there is no roadmap for the development of the halal industry, the implementation of the Halal Product Guarantee $(\mathrm{JPH})$ regulations has not been maximal., the lack of international halal certification. This regulatory challenge is corresponding to some of the results of previous research conducted by (Norazmi \& Lim, 2015; Fahham, 2017; Suhaiza et al., 2017; Faried \& Sembiring, 2019; Destiana \& Astuti, 2019; Firmansyah \& Anwar, 2019; Widiastuti et al., 2020; Anwar Fathoni \& Hadi Syahputri, 2020; Mubarok \& Imam, 2020; Muhamad, 2020; Harrieti et al., 2020; Maharani, 2020)

The phases of data analysis using the NVivo 12 plus program can be visualized in Table 3 and Figure 1. Challenges for the halal industry in Indonesia include 1) Government; 2) Organization); 3) Infrastructure; 4) Human Resources (HR); 5) Regulation

One of the challenges in developing the halal industry, which Indonesia must overcome, is Human Resources (HR). This HR challenge is in line with the Government's focus on developing human resources. The Indonesian government through the National Development Planning Agency (BAPENAS) has declared 2020 as the first year in implementing the Medium Term Development Plan (RPJMN) 2022-2024 under the theme "Increasing Human Resources for Quality Growth". There are two human resource development strategies proposed in this study, namely Human Resource Transformation and Human Resource Digitalization.

The human resource management strategies in halal industry is in accordance with Islamic values sourced from the Qur'an and Hadith. The process of Planning is in accordance with the word of Allah SWT in QS Sad (38) verse 27;

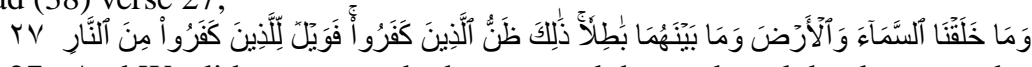

27. And We did not create the heaven and the earth and that between them aimlessly. That is the assumption of those who disbelieve, so woe to those who disbelieve from the Fire.

The process of Recruitment is in accordance with the word of Allah SWT in QS An Nisa (4) verse

58

Oبَسِيرن

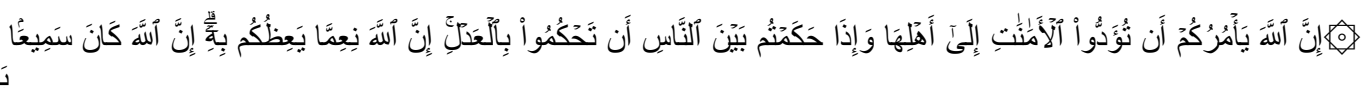


58. Indeed, Allah commands you to render trusts to whom they are due and when you judge between people to judge with justice. Excellent is that which Allah instructs you. Indeed, Allah is ever Hearing and Seeing.

The process of Selection is in accordance with the word of Allah SWT in QS Al Qashash (28) verse 26;

我

26. One of the women said, "O my father, hire him. Indeed, the best one you can hire is the strong and the trustworthy."

The process of Placement is in accordance with the word of Allah SWT in QS Al Anfal (8) verse

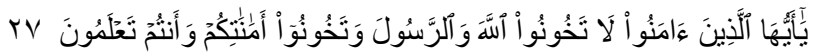

27. O you who have believed, do not betray Allah and the Messenger or betray your trusts while you know [the consequence]. (59) verse 18

The process of Career Development is in accordance with the word of Allah SWT in QS Al Hashr

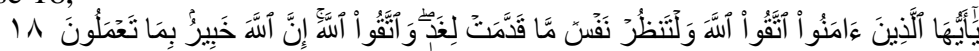

18. O you who have believed, fear Allah. And let every soul look to what it has put forth for tomorrow - and fear Allah. Indeed, Allah is Acquainted with what you do.

The process of Performance Appraisal is in accordance with the word of Allah SWT in QS Al Hujurat (49) verse 13,

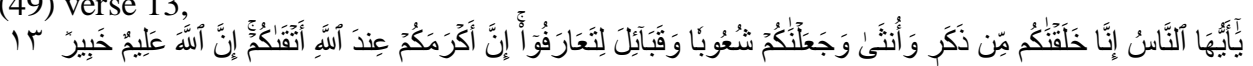

13. O mankind, indeed We have created you from male and female and made you peoples and tribes that you may know one another. Indeed, the most noble of you in the sight of Allah is the most righteous of you. Indeed, Allah is Knowing and Acquainted. and the process of Compensation is in accordance with the word of Allah SWT in QS. At taubah (9) verse 105

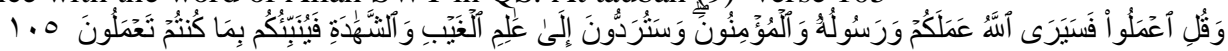

105. And say, "Do [as you will], for Allah will see your deeds, and [so, will] His Messenger and the believers. And you will be returned to the Knower of the unseen and the witnessed, and He will inform you of what you used to do."

First, Transformation of Human Resources. This HR transformation strategy includes people transformation, cultural transformation and organizational transformation as follows:

a. People Transformation;

In dealing with Human Resource challenges, companies or organizations in Indonesia need to make adjustments to the conditions of the halal industry in the future, especially in preparing themselves to become the center of the world's halal industry in 2024. The world's potential halal industry is expected to be worth approximately 2.3 trillion USD in a year (excluding Islamic finance). This is one of the markets with the fastest growth. At the same time, it is projected that global demand growth will hit an annual rate of 20 percent per annum. The growth of the halal industry is because Muslims are no longer limited to the global halal market of 2.18 billion Muslims alone. Various halal sectors, such as food and beverages, halal pharmaceuticals and cosmetics, halal clothing, halal tourism, halal media and entertainment, and Islamic finance as well as service sector components such as logistics, marketing, print and electronic media, packaging, branding, and financing.

This person's transformation strategy is related to the HR planning process, from the recruitment phase to upcoming pension preparation. HR management using a data-based approach needs to be optimized so that it can produce the right, fast, and perfect recommendations to be used as a basis for strategic decision making. The present condition, where the millennial generation begins to dominate the industry, requires companies to be more innovative, creative and aggressive in improving HR enrollment patterns. Additionally, the HR development program needs to be managed and implemented systematically and its sustainability is retained, in order to create talents and skills that are equipped in the future. Conversely, the organization can offer a Retention Program which has been packaged in an attractive and creative way to ensure that the best and talented talents can contribute its expertise longer and be involved in the company. Preparation programs for retirement also essential to be well developed and planned, so that human resources or employees can get themselves ready well for retirement, including physical, mental and financial readiness. This person transformation strategy is in line with a number of studies related to HR development that have been carried out by (Robertson, 2000; Rochaeni, 2008; Bondarouk \& Ruël, 2009; and Eckhardt et al., 2014).

b. Cultural Transformation

The strategy of cultural transformation in organizations because there are many things that must be anticipated, for example, often the HR department finds employees who are resistant to conditions that have experienced many changes in the corporate environment such as the use of digital technology (digital technology) which has an impact on changes in company business processes and changes in models business of a company. In an effort to reduce the emergence of a culture gap or cultural differences between changing conditions and current 
working conditions, a cultural activation program is needed which can refer to three main objectives, namely the company's vision and mission, Employee Value Proportion (EVP), namely how companies provide a set of values as attractiveness for new talents and core values, namely the core values that exist in the company in order to shape behavior, attitudes and character in the work environment in order to foster a company culture. The cultural activation program is not only for corporation staffs, but also for prospective employees who wish to work for the company. In the selection process for potential employees, it is necessary to pay attention to competency standards, superior personality, and character of prospective employees that are in line with the company culture. The goal is to minimize the culture gap from the start so that new employees can adapt well, quickly and work optimally. This strategy is in accordance with the results of research conducted by (Tjahjaningsih, 2012; Perbawasari \& Setianti, 2013; Lamsihar \& Huseini, 2019).

c. Organizational Transformation

The existence of HR in organizations today is very different from the existence of HR in the past. The difference lies in the preoccupation of organizations in the past in carrying out administrative work, whereas in today's conditions organizations are required to have a role as a strategic business partner which is expected to be able to contribute to the success of company performance. Organizations are required to be able to have a good grip of the company's business processes, the company's business model, as well as be a reliable business partner in dealing with HR-related issues and the organization is also required to understand the company's financial condition. This organizational transformation strategy is in accordance with prior research conducted by (Sackmann, 1989; Shields, 1999; Choi, 2004; McGuire et al., 2009; and Schalock et al., 2018)

Second, the digitization of human resources. The digitization of the HR system is very significant to do comprehensively in an effort to assist organizations in preparing strategic planning, HR management, and data-based strategic decision making. The chief role of organizations in developing the quality of human resources through corporate universities through training programs and development programs in accordance with company goals. The next step, a corporate university must be proactive and take the initiative in submitting input for business solutions to companies based on scientific studies. This HR digitization strategy scrutiny is in line with several studies that have been conducted by (Robertson, 2000; Leda et al., 2007; Bissola \& Imperatori, 2018; Hartati, 2020; and Vardarlier, 2020).

\section{Description of the Case: Digital Government and Public Library in the Regency of Bojonegoro}

The regency of Bojonegoro represents one of the most innovative and progressive regencies in using ICTs to promote openness and participation. The effort with the adoption of open government principles since March 2008 by firstly encouraging public discussion and participation were combining offline meetings and interactive dialog through public radio called "Radio Malowati Madani" (Adarma, 2017). The use of ICTs to support the openness and participation started in July 2014 through the implementation of two web-based applications called "Integrated Public Aspiration Systems (SIAP)" and "Public Aspiration Online Services (LAPOR!)." The apps enable the public to express their opinions, ideas, critiques, grievances, and input to the government (Heriyanto, 2017). Government agencies receiving complaints have five working days to respond to and resolve the issue (Heriyanto, 2017). Since then, the government extend the reach of the apps to every village within the regency jurisdictions.

Bojonegoro regency started to embrace the concept of Smart City when it was chosen to become part of the 25 cities/regencies pioneer to adopt a smart city as part of the " 100 smart city movement" in Indonesia. Bojonegoro advances the smart city effort by putting forward smart people as their first target (Bojonegoro, 2019). With this objective, the regency aims to create a productive, communicative, and interactive society with high digital literacy. Specifically, the regency objective is to develop sociotechnical ecosystems for humanist and dynamic society, both physically and virtually. For that, the regency aims to promote an ecosystem for efficient learning and community interactions. Here are some of the programs in the Bojonegoro's smart city strategies: a) an improvement on the management, restoration, and preservation of the regional documents and archives system, b) the development of e-library and e-learning to improve education services, c) strengthening public participation and consultation mechanism particularly at the sub-districts and village level, d) promotion and training for smart, healthy, and free of discriminations social uses, and e) an improvement in the digital literacy within the regency.

Achieving a smart library is thus part of Bojonegoro's smart city strategies. In recent, there are three major programs of the Bojonegoro public library. First is the implementation of an electronic library (e-library) and e-learning. Second is the integration of the public library with the surrounding school libraries and the provincial public libraries. Third is in promoting e-administration specifically for archive management. Bojonegoro public library also implements online catalog services in $2019 \mathrm{https} / / / \mathrm{katalog}$ dinasperpusarsipbojonegoro.perpusnas.go.id/. To cater to the needs of the primary users, students from schools and universities around Bojonegoro (Mubarok, 2018), the public library is expanding their reach by developing village libraries, training librarians for village libraries, and operating mobile libraries (ojenews, 2019). To further expand the effort for a smart library, Bojonegoro public library 
also conducted several innovative programs such as storytelling for students, web design training, entrepreneurship training, and others (Nugroho, 2019).

\section{Conclusions, suggestions and limitations}

Based on the analysis of literature studies, there are 5 (five) challenges encountered by the halal industry in Indonesia, comprising; 1) Regulation; 2) Human Resources (HR); 3) Government; 4) Infrastructure; 5) Organization and there are 2 (two) HR development strategies that can be carried out, namely 1) Human Resource Transformation through people transformation, cultural transformation, organizational transformation and 2) Human Resource Digitalization.

The practical applications of this research compiles the human resources development strategies of the halal industry in Indonesia. This strategy focuses on Human Resource Transformation and Human Resource Digitalization. Therefore, it will be easier to continue the strategy of Regulation, Government, Infrastructure and Organization into the halal industry development program in Indonesia.

The limitation of this study is simply to analyze the challenges of the halal industry in general, and not to specifically select one sector of the halal industry. Likewise, this analysis only observes HR development strategies in an effort to face the challenges faced by Indonesia as the center of the halal industry in 2024 and does not analyze the strategies of all the existing challenges.

\section{References}

A.J., W. J., \& Jonathan, L. (2011). The challenges of Islamic branding: navigating emotions and halal. Journal of Islamic Marketing, 2(1), 28-42. https://doi.org/10.1108/17590831111115222

Abduttawwab, M. (2019). Halal recreation potential in Indonesia in improving tourists and the global economy. 94902.

Aisyah, M. (2016). Consumer Demand on Halal Cosmetics and Personal Care Products in Indonesia. AlIqtishad: Jurnal Ilmu Ekonomi Syariah, 9(1), 125-142.

Ali Hasan, H., \& Azis Muslimin, A. (2019). Ambiguity on Syariah Tourism In Indonesia. Humanities \&amp; Social Sciences Reviews, 7(5 SE-Economics \&amp; Commerce), 609-617. https://doi.org/10.18510/hssr.2019.7570

Anwar Fathoni, M., \& Hadi Syahputri, T. (2020). Potret Industri Halal Indonesia: Peluang dan Tantangan. Jurnal Ilmiah Ekonomi Islam, 6(03), 428-435. http://jurnal.stieaas.ac.id/index.php/jiedoi:http://dx.doi.org/10.29040/jiei.v6i3.1146

Arbak, S., Islam, R., \& Al Rasyid, H. (2019). Relationship Between Advertisement and Purchase Intention on Halal Cosmetic Products In Malaysia. Humanities \&amp; Social Sciences Reviews, 7(3 SEEconomics \&amp; Commerce), 683-694. https://doi.org/10.18510/hssr.2019.7399

Baidhowi, B. (2018). Sharia Banking Opportunities and Challenges in the Digital Era. 1st International Conference on Indonesian Legal Studies (ICILS 2018).

Barizah, M. R. N. (2020). Halal Certification of Patented Medicines In Indonesia In Digital Age: A Panacea for The Pain? Systematic Reviews in Pharmacy, 11(12), 210-217.

Battour, M., \& Ismail, M. N. (2016). Halal tourism: Concepts, practises, challenges and future. Tourism Management Perspectives, $19, \quad 150-154$. https://doi.org/https://doi.org/10.1016/j.tmp.2015.12.008

Bissola, R., \& Imperatori, B. (2018). HRM 4.0: The digital transformation of the HR Department.

Bondarouk, T., \& Ruël, H. J. M. (2009). Structuring the IT-enabled transformation of HR: An HRM frames analysis in an international company. Handbook of International Human Resource Management: Integrating People, Process, and Context, 271-292.

Briliana, V., \& Mursito, N. (2017). Exploring antecedents and consequences of Indonesian Muslim youths' attitude towards halal cosmetic products: A case study in Jakarta. Asia Pacific Management Review, 22(4), 176-184.

Choi, J. (2004). Transformation of Korean HRM based on Confucian values. 10(1), 1-26.

Delma, P., Sharon, P., \& Joanne, S. (2015). Traceability systems in the Western Australia halal food supply chain. Asia Pacific Journal of Marketing and Logistics, 27(2), 324-348. https://doi.org/10.1108/APJML-05-2014-0082

Destiana, R., \& Astuti, R. S. (2019). Pengembangan Pariwisata Halal di Indonesia. Conference on Public Administration and Society, l(01).

Eckhardt, A., Laumer, S., Maier, C., \& Weitzel, T. (2014). The transformation of people, processes, and IT in e-recruiting: Insights from an eight-year case study of a German media corporation. Employee Relations, 36(4), 415-431. 
Erhan, B., \& Mehmet, S. (2019). Halal tourism: conceptual and practical challenges. Journal of Islamic Marketing, 10(1), 87-96. https://doi.org/10.1108/JIMA-06-2017-0066

Fahham, A. M. (2017). Tantangan Pengembangan Wisata Halal Di Nusa Tenggara Barat. Jurnal Aspirasi, $8(1), 65-79$.

Faried, A. I., \& Sembiring, R. (2019). Enhance Of Halal Rule Development Model On Fashion Industry Indonesia. 24(9), 26-32.

Firmansyah, E. A., \& Anwar, M. (2019). Islamic financial technology (FINTECH): its challenges and prospect. Achieving and Sustaining SDGs 2018 Conference: Harnessing the Power of Frontier Technology to Achieve the Sustainable Development Goals (ASSDG 2018).

Hanzaee, K. H., \& Chitsaz, S. (2011). A review of influencing factors and constructs on the Iranian women 's Islamic fashion market. Interdisciplinary Journal of Research in Business, 1(April), 94-100.

Harrieti, N., Abubakar, L., Djukardi, E., \& Nurhasanah, N. (2020). Integration of Commercial Finance and Social Finance: Challenges of Sharia Banking in Indonesia. Journal of Legal, Ethical and Regulatory Issues, 23(2), 1-13.

Hartati, I. (2020). Strategi Pembangunan SDM Kementerian Keuangan Republik Indonesia dalam Menghadapi Tantangan Era Disrupsi 4.0. Jurnal BPPK: Badan Pendidikan Dan Pelatihan Keuangan, 13(1), 109-129.

Haseeb, M. (2018). Emerging issues in Islamic banking \& finance: Challenges and solutions. Academy of Accounting and Financial Studies Journal, 22(Specialissue), 3685.

Izzuddin, Z. M., Faridah, H. H., \& Kadir, O. A. (2019). Halal brand personality and brand loyalty among millennial modest fashion consumers in Malaysia. Journal of Islamic Marketing, 11(6), 12771293. https://doi.org/10.1108/JIMA-10-2018-0187

Jaelani, A. (2017). Halal Tourism Industry in Indonesia: Potential and Prospects. SSRN Electronic Journal. https://doi.org/10.2139/ssrn.2899864

Lamsihar, A. T., \& Huseini, M. (2019). Transformasi Budaya dan Inovasi Perusahaan BUMN. Inovbiz: Jurnal Inovasi Bisnis, 7(1), 64-70.

Leda, P., Maria, V., \& Eleanna, G. (2007). E-HR adoption and the role of HRM: evidence from Greece. Personnel Review, 36(2), 277-294. https://doi.org/10.1108/00483480710726145

Limsuwan, P. (2019). The Analysis Of Perceived Value Factors Affecting Parents' To Purchase Packaged Baby Food Products In Thailand. Humanities \&amp; Social Sciences Reviews, 7(5 SE-Economics \&amp; Commerce), 318-326. https://doi.org/10.18510/hssr.2019.7537

Maharani, S. (2020). The Beyond Challenges Of Indonesia Sharia Banking In The Digitalization Era.

Majid, M. A. A., Abidin, I. H. Z., Majid, H. A. M. A., \& Chik, C. T. (2015). Issues of Halal Food Implementation in Malaysia Chemah TAMBY CHIK. Journal of Applied Envirenmental and Biologcal Sciences, 5(6S), 50-56. www.textroad.com

Majid, M. B., Sabir, I., \& Ashraf, T. (2015). Consumer Purchase Intention towards Halal Cosmetics \& Personal Care Products in Pakistan. Global of Research in Business \& Management, 1(1), 45-53.

Martiana, A., Maesyaroh, \& Sobar. (2018). Motivation and obstacles faced by women halal fashion entrepreneurs and role of the business on women's economic empowermentin Yogyakarta Indonesia. Humanities and Social Sciences Reviews, 6(2), 106-110. https://doi.org/10.18510/hssr.2018.6213

Masrom, Daut, Rasi R.Z., R. M., \& Niraula. (2019). Evaluation Of The Business Excellent Implementation Among Halal Certified Food Manufacturers In Malaysia. Humanities \&amp; Social Sciences Reviews, $\quad 7(2 \quad$ SE-Economics $\quad$ \&amp; Commerce), 220-225. https://doi.org/10.18510/hssr.2019.7224

McGuire, J. B., Palus, C. J., Pasmore, W., \& Rhodes, G. B. (2009). Transforming your organization. Greensboro: Center for Creative Leadership.

Mubarok, F. K., \& Imam, M. K. (2020). Halal Industry in Indonesia; Challenges and Opportunities. Journal of Digital Marketing and Halal Industry, 2(1), 55. https://doi.org/10.21580/jdmhi.2020.2.1.5856

Muhamad, M. (2020). Tantangan Dan Peluang Penerapan Kebijakan Mandatory Sertifikasi Halal (Studi Implementasi Uu No. 33 Th. 2014 dan Pp No. 31 Th. 2019). Jurnal Ilmu Ekonomi Dan Bisnis Islam, 2(2), 1-26.

Mujahidin, M. (2019). Opportunities and Challenges of Sharia Technology Financials in Indonesia. 94844.

Nadira, R. roro azka. (2020). Potensi Industri Halal di Indonesia. https://www.ibec-febui.com/potensiindustri-halal-di-indonesia/

Nisha, N., \& Iqbal, M. (2017). Halal ecosystem: Prospect for growth in Bangladesh. International Journal of Business and Society, 18(S1), 205-222. 
Norazmi, M. N., \& Lim, L. S. (2015). Halal pharmaceutical industry: opportunities and challenges. Trends in Pharmacological Sciences, 36(8), 496-497.

Perbawasari, S., \& Setianti, Y. (2013). Komunikasi Dalam Transformasi Budaya Perusahaan. Dalam Jurnal Penelitian Komunikasi, 16, 1-12.

Rasit, R. M., Hamjah, S. H., Misrom, A., \& Yahya, N. H. (2019). Socio-Cultural Discourse Of Muslim Society In Social Semiotics Aspect Of Advertising Text In Malaysia. Humanities \&amp; Social Sciences Reviews, 7(5 SE-Sociology), 256-263. https://doi.org/10.18510/hssr.2019.7531

Rasul, T. (2019). The trends, opportunities and challenges of halal tourism: a systematic literature review. Tourism Recreation Research, 44(4), 434-450. https://doi.org/10.1080/02508281.2019.1599532

Robertson, K. (2000). Work transformation: integrating people, space and technology. Facilities.

Rochaeni, A. (2008). Strategi Pengembangan Sumber Daya Manusia dalam Era Kompetisi. Manajerial, 410.

Sackmann, S. (1989). The role of metaphors in organization transformation. Human Relations, 42(6), 463485.

Satriana, E. D., \& Faridah, H. D. (2018). Halal Tourism: Development, Chance and Challenge. Journal of Halal Product and Research, 1(2), 32. https://doi.org/10.20473/jhpr.vol.1-issue.2.32-43

Sayogo, D. S. (2018). Online traceability for halal product information: perceptions of Muslim consumers in Indonesia. JOURNAL OF ISLAMIC MARKETING, 9(1), 99-116. https://doi.org/https://doi.org/10.1108/JIMA-07-2016-0057

Sayogo, D., Yuli, S., Munarko, Y., \& Zuhroh, I. (2017). Taxonomy to Support Traceability System for Smart Disclosure of Halal Product Information. JNIT (Journal of Next Generation Information Technology), 8(4), 29-38.

Schalock, R. L., Verdugo, M. A., \& van Loon, J. (2018). Understanding organization transformation in evaluation and program planning. Evaluation and Program Planning, 67, 53-60.

Shields, J. L. (1999). Transforming organizations. Information Knowledge Systems Management, 1(2), 105-115.

Sugibayashi, K., Yusuf, E., Todo, H., Dahlizar, S., Sakdiset, P., Arce Jr, F., \& See, G. L. (2019). Halal cosmetics: A review on ingredients, production, and testing methods. Cosmetics, 6(3), 37.

Suhaiza, Z., Mohammad, I., Azliza, A. A., \& Kanagi, K. (2017). Halal logistics opportunities and challenges. Journal of Islamic Marketing, 8(1), 127-139. https://doi.org/10.1108/JIMA-04-20150028

Suyudi, M., Muhlis, M., \& Mansur, M. (2019). Pesantren Sebagai Pusat Sertifikasi Dan Edukasi Sumber Daya Insani Pariwisata Syariah Dalam Penguatan Industri Halal Di Indonesia. Dinar: Jurnal Ekonomi Dan Keuangan Islam, 6(2), 135-145.

Tjahjaningsih, E. (2012). Upaya Peningkatan Kinerja Organisasi Melalui Inovasi Transformasi Budaya Prososial. Seminar Nasional Dan Call for Paper.

Triyono. (2013). Budaya Organisasi (Studi Eksplorasi pada Universitas Muhammadiyah Semarang). Value Added, 9(1), 1-20.

Vardarlier, P. (2020). Digital transformation of human resource management: digital applications and strategic tools in HRM. In Digital Business Strategies in Blockchain Ecosystems (pp. 239-264). Springer.

Waharini, F. M., \& Purwantini, A. H. (2018). Model Pengembangan Industri Halal Food di Indonesia.

Warsito, C., Sholikhah, A., Rabiatul Adawiyah, W., \& Pradipta Setyanto, R. (2020). Antecedents Of Consumers' Decision For Halalmart Shopping: The Moderating Role Of Family Religious Commitment. Humanities \&amp; Social Sciences Reviews, $8(1$ SE-Economics \&amp; Commerce), 152-164. https://doi.org/10.18510/hssr.2020.8122

Warto, \& Arif, Z. (2020). Bisnis Produk Halal antara Peluang dan Tantangan, Problematika dan Halal Product Business Between Opportunities and Challenges, Problematics and Their Solutions Bisnis Produk Halal antara Peluang dan Tantangan , Problematika dan Solusinya Author corresp. Al-Ulum, 20(1), 274-294.

Widiastuti, T., Rusydiana, A. S., Robani, A., Insani, T. D., \& Muryani. (2020). Obstacles and Strategies in Developing Halal Industry: Evidence From Indonesia. Humanities \& Social Sciences Reviews, 8(4), 398-406. https://doi.org/10.18510/hssr.2020.8439 
